\title{
Conversion of cell-survival activity of Akt into apoptotic death of cancer cells by two mutations on the BIM BH3 domain
}

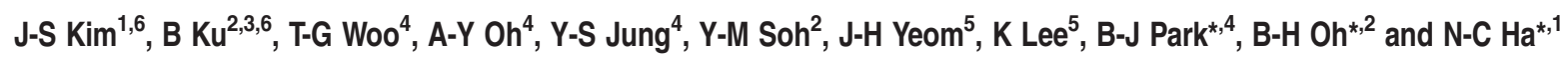

Survival and proliferation of cancer cells are often associated with hyperactivity of the serine/threonine kinase, Akt. Herein, we show that prosurvival activity of Akt can be converted into prodeath activity by embedding an Akt recognition sequence in the apoptogenic $\mathrm{BH} 3$ domain of human BIM. The recognition sequence was created by introducing two mutations, I155R and E158S, into the core region of the BIM BH3 domain. Although a 21-mer BIM BH3 peptide containing these two mutations bound weakly to $B C L-X_{L}$ and BCL-2, this peptide with phosphorylation of Ser158 bound to these proteins with a dissociation constant of $<10 \mathrm{nM}$. The crystal structure of the phosphorylated peptide bound to BCL- $X_{L}$ revealed that the phospho-Ser158 makes favorable interactions with two BCL- $\mathrm{X}_{\mathrm{L}}$ residues, which cannot be formed with unphosphorylated Ser158. Remarkably, the designed peptide showed a cytotoxic effect on PTEN-null PC3 tumor cells whose Akt activity is aberrantly high. The cell-killing activity disappeared when the cellular Akt activity was lowered by ectopic PTEN expression. Thus, these results lay a foundation for developing a peptide or protein agent that is dormant in normal cells but is transformed into a potent apoptogenic molecule upon phosphorylation by hyperactivity of Akt in cancer cells.

Cell Death and Disease (2015) 6, e1804; doi:10.1038/cddis.2015.118; published online 2 July 2015

The interplay between the BCL-2 family proteins regulates mitochondrion-mediated apoptotic cell death. ${ }^{1,2}$ The BCL-2 family proteins are characterized by having at least one BCL-2 homology $(\mathrm{BH})$ domain, and they are classified into three distinct subgroups based on their functional and structural features. One subgroup consists of BAX and BAK, which contain the $\mathrm{BH} 1-\mathrm{BH} 4$ domains and mediate apoptosis by increasing the permeability of the mitochondrial outer membrane (MOM) and thus leading to the release of the apoptogenic factors, such as cytochrome $c$ and Smac/Diablo. ${ }^{3-6}$ Another subgroup is composed of antiapoptotic proteins, BCL-2, BCL- $X_{L}, B C l-w, M C L-1, A 1$ and BCL-B, which contain the $\mathrm{BH} 1-\mathrm{BH} 4$ domains that are arranged to form an extended hydrophobic groove known as the BH3-binding groove. ${ }^{7}$ The remaining subgroup is composed of a diverse set of proteins that are unrelated to each other except for the possession of the $\mathrm{BH} 3$ domain. ${ }^{7}$ These $\mathrm{BH} 3$-only proteins sense and convey apoptotic cell death signals, ultimately leading to the activation of BAX and BAK. ${ }^{8,9}$ The antiapoptotic BCL-2 subfamily proteins bind the $\mathrm{BH} 3$ domain of $\mathrm{BAX} / \mathrm{BAK}$ and of the $\mathrm{BH} 3$-only proteins through their BH3-binding groove. ${ }^{10-15}$

Biochemical studies have discovered that a number of the BH3-only proteins termed 'activators', such as BID and BIM, bind directly to $B A X$ and induce its activation, whereas other BH3-only proteins termed 'sensitizers' induce apoptosis by releasing the activators sequestered by the antiapoptotic proteins. ${ }^{5,16,17}$ A recent crystallographic study revealed that the BID BH3 peptide binds to the canonical $\mathrm{BH} 3-$ binding groove of BAX and induces a pronounced conformational change that exposes the $\mathrm{BH} 3$ domain of $\mathrm{BAX} .{ }^{18}$ The activated BAX oligomerizes to induce the permeabilization of the MOM. ${ }^{6}$ The antiapoptotic BCL-2 proteins were suggested to sequester the $\mathrm{BH} 3$ domains of both $\mathrm{BAX}$ and the activator $\mathrm{BH} 3$-only proteins to prevent the BAX oligomerization. ${ }^{18}$

Apoptosis is attenuated in cancer cells because of the abundance of antiapoptotic BCL-2 proteins and/or prevention of apoptosis induction. Anticancer BH3 peptides have been developed, especially those derived from BIM, which interacts with all of the antiapoptotic proteins with extremely high affinity. ${ }^{15,19}$ These BH3 peptides exhibit a broad and multimodal targeting of the BCL-2 family proteins. ${ }^{20-22}$ Promising small molecular anticancer compounds have also been developed that mimic the $\mathrm{BH} 3$ peptides and bind to the surface groove of the antiapoptotic proteins. ${ }^{23}$ ABT-737 and ABT-263 selectively bind to and lower the amounts of the functional BCL-2, BCL- $X_{L}$ and BCL-w proteins to induce the

\footnotetext{
${ }^{1}$ Department of Agricultural Biotechnology, Center for Food Safety and Toxicology, Research Institute for Agriculture and Life Sciences, Seoul National University, Seoul, Republic of Korea; ${ }^{2}$ Department of Biological Sciences, KAIST Institute for the Biocentury, Cancer Metastasis Control Center, Korea Advanced Institute of Science and Technology, Daejeon, Republic of Korea; ${ }^{3}$ Functional Genomics Research Center, Korea Research Institute of Bioscience and Biotechnology, Daejeon, Republic of Korea; ${ }^{4}$ Department of Molecular Biology, Pusan National University, Busan, Republic of Korea and ${ }^{5}$ Department of Life Science, Chung-Ang University, Seoul, Republic of Korea ${ }^{*}$ Corresponding author: B-J Park or B-H Oh or N-C Ha, Department of Agricultural Biotechnology, Seoul National University, Center for Food Safety and Toxicology, Research Institute for Agriculture and Life Sciences, 1, Gwanak-ro, Gwanak-gu, Seoul 151-921, Republic of Korea. Tel: +82 515102220 ; Fax: +82 51 513 9258 ; E-mail: bjpark1219@pusan.ac.kr (B-J Park) or Tel: +82 42350 2648; Fax: +82 42350 2610; E-mail: bhoh@ kaist.ac.kr (B-H Oh) or Tel: +82 28804853 ; Fax: +82 2873 5095; E-mail: hanc210@snu.ac.kr (N-C Ha)

${ }^{6}$ These authors contributed equally to this work.

Abbreviations: BH, BCL-2 homology; MOM, mitochondrial outer membrane; ITC, isothermal titration calorimetry; AuNP, gold nanoparticle; NSCLS, non-small cell lung cancer

Received 26.10.14; revised 24.3.15; accepted 24.3.15; Edited by G Dewson
} 
apoptotic death of tumor cells that depend especially on the overexpression of the three proteins. ${ }^{24,25}$ The $\mathrm{BH} 3$ peptides and the $\mathrm{BH} 3$ mimetics both bear an intrinsic shortcoming in that they inhibit the BCL-2 family proteins not only in cancer cells but also in normal cells as they cannot distinguish cancerous from normal cells.

One of the hallmarks of many cancer and tumor cells is the hyperactivation of the serine/threonine (Ser/Thr) protein kinase Akt, which is a key signaling molecule in the cellular survival pathway. ${ }^{26}$ In many types of cancers, including glioma, prostate cancer and breast cancer, Akt is required to maintain a proliferative state and for progression into a more malignant state in conjunction with genetic mutations. ${ }^{26-28}$

We set out to develop a molecule that can respond to the hyperactivity of Akt and can lead to the death of cancer cells. Herein, we describe the embedment of the Akt recognition sequence into the BIM BH3 peptide and the cancer cellspecific apoptogenic property of the resulting $\mathrm{BIM} \mathrm{BH} 3$ peptide variant characterized by $\mathrm{X}$-ray crystallography, calorimetry and cell-based biochemistry.

\section{Results}

Design of a $\mathrm{BIM} \mathrm{BH} 3$ peptide with an Akt recognition sequence. We chose the $\mathrm{BIM} B \mathrm{BH}$ as the template sequence for mutagenesis. According to the crystal structure of the mouse $\mathrm{BIM} \mathrm{BH3}$ domain bound to $B C L-X_{L}, 21$ residues of $\mathrm{BIM}$ form the core region of the $\mathrm{BH} 3$ domain that spans the surface groove of $B C L-X_{L}{ }^{14}$ The 21 residues correspond to 145-EIWIAQELRRIGDEFNAYYAR-165 of human BIM, which is referred to as $\mathrm{BH}_{\mathrm{BIM}}$ (Figure 1). To design a $\mathrm{BH} 3_{\mathrm{BIM}}$ peptide variant that can be phosphorylated by Akt, we noted

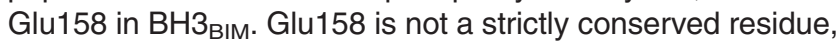
but is involved in a polar interaction with Tyr101, a conserved residue of $B C L-X_{L}$ in the crystal structure, ${ }^{14}$ suggesting that this residue contributes to the binding affinity of $\mathrm{BH}_{\mathrm{BIM}}$. Thus, it was expected that a $\mathrm{BH}_{\mathrm{BIM}}$ variant containing serine in place of Glu158 would exhibit reduced binding affinity for the antiapoptotic BCL-2 family proteins, but phosphorylation of Ser158 could restore the binding affinity since phosphorylated serine often serves as a mimic of glutamate residue. Importantly, this variant peptide turns into an Akt recognition sequence by a second mutation of lle155Arg, because the doubly mutated sequence has a $R R R^{155} \mathrm{GD} S^{158} \mathrm{~F}$ stretch that conforms to the Akt recognition sequence (RxRxxT/SF; T/S, phosphorylation site). ${ }^{29}$ lle155 of human BIM, which is a strictly conserved residue, is involved in extensive hydrophobic interactions with $B C L-X_{L}$ in the complex between mouse BCL- $X_{L}$ and a BIM BH3 peptide. ${ }^{14}$ Nonetheless, a modeling experiment with this $\mathrm{BH}_{\mathrm{BIM}}$ peptide variant,

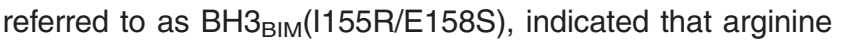
in place of lle155 is sterically compatible and does not completely abrogate the binding interaction. In addition, its guanidinium group seemed to form an intramolecular salt bridge with Glu151 in this peptide.

In particular, phosphorylated Ser158, not Ser158, of BIM appeared to form a polar interaction with Tyr101 of BCL-X $X_{L}$. Furthermore, the phosphate group on Ser158 was within the intramolecular ionic-bonding distance from the guanidinium group of Arg154. Based on these expectations, we hypothesized that unphosphorylated $\mathrm{BH}_{\mathrm{BIM}}(\mathrm{I155R/E158S)}$ would suffer from reduction in the binding affinity compared with the wild-type version, but phosphorylation of the peptide at Ser158 could provide some compensation by directly interacting with $B C L-X_{L}$. Thus, it seemed plausible that a full-length BIM or a $\mathrm{BH} 3$ region bearing the $\mathrm{I155R}$ and $\mathrm{E} 158 \mathrm{~S}$ substitutions could be phosphorylated in cancer cells with elevated Akt activity and then be converted into a potent inhibitor against antiapoptotic BCL-2 proteins, while they are not potentiated in normal cells due to low or controlled Akt activity.

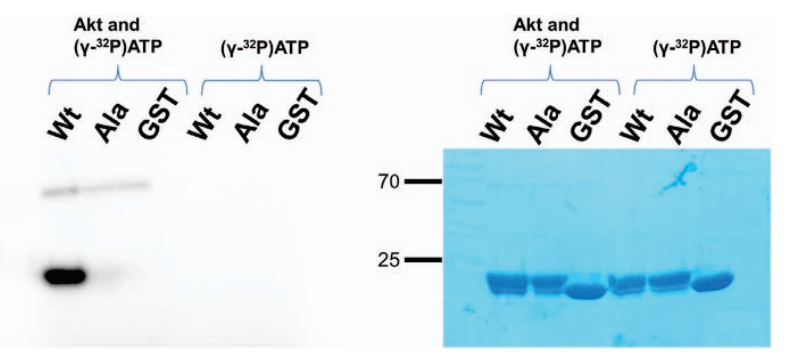

Figure 2 In vitro Akt kinase assay. GST-fused $\mathrm{BH}_{\mathrm{BIM}}(1155 \mathrm{R} / \mathrm{E} 158 \mathrm{~S})$ (WT), $\mathrm{BH}_{\mathrm{BIM}}(1155 \mathrm{R} / \mathrm{E} 158 \mathrm{~A})$ (Ala) or GST was incubated with ATP and $\left[\gamma^{-}{ }^{32} \mathrm{P}\right] \mathrm{ATP}$ in the presence or absence of Akt. The mixtures were resolved on a SDS-polyacrylamide gel, and the radioactivity (left panel) and Coomassie-staining (right panel) are shown. Only GST-fused $\mathrm{BH}_{\mathrm{BIM}}(1155 \mathrm{R} / \mathrm{E} 158 \mathrm{~S})$ was phosphorylated

\begin{tabular}{|c|c|c|c|c|c|c|c|c|c|c|c|c|c|c|c|c|c|c|c|c|c|}
\hline \multirow[b]{2}{*}{ BH $3_{B I M}$} & \multirow[b]{2}{*}{$E$} & \multirow[b]{2}{*}{1} & \multirow[b]{2}{*}{ W } & \multirow[b]{2}{*}{1} & \multirow[b]{2}{*}{ A } & \multirow[b]{2}{*}{$Q$} & \multirow[b]{2}{*}{$E$} & \multirow[b]{2}{*}{$\mathrm{L}$} & \multicolumn{4}{|c|}{154155} & \multicolumn{3}{|c|}{158} & \multirow[b]{2}{*}{$\mathrm{N}$} & \multirow[b]{2}{*}{ A } & \multirow[b]{2}{*}{$\mathrm{Y}$} & \multirow[b]{2}{*}{$\mathrm{Y}$} & \multirow[b]{2}{*}{ A } & \multirow[b]{2}{*}{$\mathrm{R}$} \\
\hline & & & & & & & & & $\mathrm{R}$ & $\mathrm{R}$ & 1 & G & $\mathrm{D}$ & $E$ & $\mathrm{~F}$ & & & & & & \\
\hline BH3 & $E$ & 1 & W & I & A & Q & $E$ & $\mathrm{~L}$ & $\mathrm{R}$ & $\mathrm{R}$ & $\mathbf{R}$ & G & $\mathrm{D}$ & $\mathbf{S}$ & $\mathrm{F}$ & $\mathrm{N}$ & A & $\mathrm{Y}$ & $Y$ & A & $\mathrm{R}$ \\
\hline p-BH3вІм (I155R/E158S) & $E$ & 1 & W & 1 & A & Q & $E$ & $\mathrm{~L}$ & $\mathrm{R}$ & $\mathrm{R}$ & $\mathbf{R}$ & G & D & ps & $\mathrm{F}$ & $\mathrm{N}$ & A & $\mathrm{Y}$ & $\mathrm{Y}$ & A & $\mathrm{R}$ \\
\hline BH3 & $E$ & 1 & W & 1 & A & Q & $E$ & $\mathrm{~L}$ & $\mathrm{R}$ & $\mathrm{R}$ & $\mathbf{R}$ & G & $\mathrm{D}$ & A & $\mathrm{F}$ & $\mathrm{N}$ & A & $\mathrm{Y}$ & $\mathrm{Y}$ & A & $\mathrm{R}$ \\
\hline BH3 & $E$ & 1 & W & 1 & A & Q & $E$ & $\mathrm{~L}$ & $\mathrm{R}$ & $\mathbf{s}$ & $\mathbf{R}$ & G & $\mathrm{D}$ & $\mathbf{S}$ & $\mathrm{F}$ & $\mathrm{N}$ & A & $\mathrm{Y}$ & Y & A & $\mathrm{R}$ \\
\hline p-BH3 ${ }_{\text {BIM }}(\mathrm{R} 154 \mathrm{~S} / 1155 \mathrm{R} / \mathrm{E} 158 \mathrm{~S})$ & $E$ & 1 & W & 1 & A & Q & $E$ & $\mathrm{~L}$ & $\mathrm{R}$ & $\mathbf{s}$ & $\mathbf{R}$ & G & $\mathrm{D}$ & ps & $\mathrm{F}$ & $\mathrm{N}$ & A & $\mathrm{Y}$ & Y & A & $\mathrm{R}$ \\
\hline ВH3 & $E$ & I & W & 1 & A & Q & $E$ & $\mathrm{~L}$ & $\mathrm{R}$ & $\mathrm{R}$ & I & G & $D$ & $\mathbf{S}$ & $F$ & $\mathrm{~N}$ & $E$ & $\mathrm{~T}$ & $Y$ & $A$ & $\mathrm{R}$ \\
\hline
\end{tabular}

Figure 1 Amino acid sequences of the peptides used in this study. The substituted residues are in red, and 'pS' stands for the phosphorylated serine residue 
$B H 3_{\mathrm{BIM}}(\mathrm{I155R} / \mathrm{E} 158 \mathrm{~S})$ is phosphorylated by Akt and potently binds to antiapoptotic BCL-2 proteins. To examine whether the designed sequence is phosphorylated by Akt as we intended, we carried out an in vitro Akt activity assay by using GST-tagged $\mathrm{BH}_{\mathrm{BIM}}(\mathrm{I} 155 \mathrm{R} / \mathrm{E} 158 \mathrm{~S})$ as the substrate in the presence of $\left[\gamma^{-}{ }^{32} \mathrm{P}\right] A T P$. GST-tagged $\mathrm{BH}_{\mathrm{BIM}}($ I155R/E158S) was efficiently phosphorylated, while GST and GST-tagged $\mathrm{BH}_{\mathrm{BIM}}(1155 \mathrm{R} / \mathrm{E} 158 \mathrm{~A})$ employed as

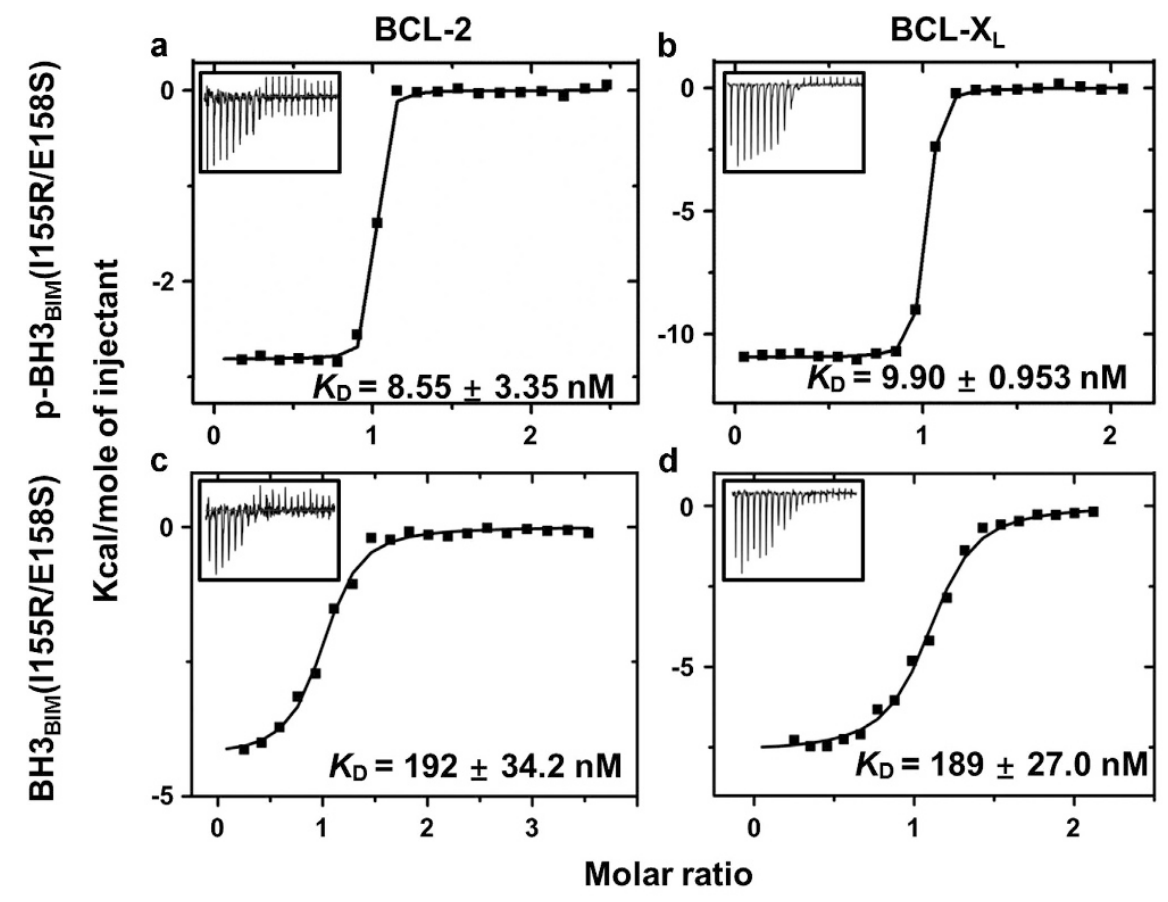

e

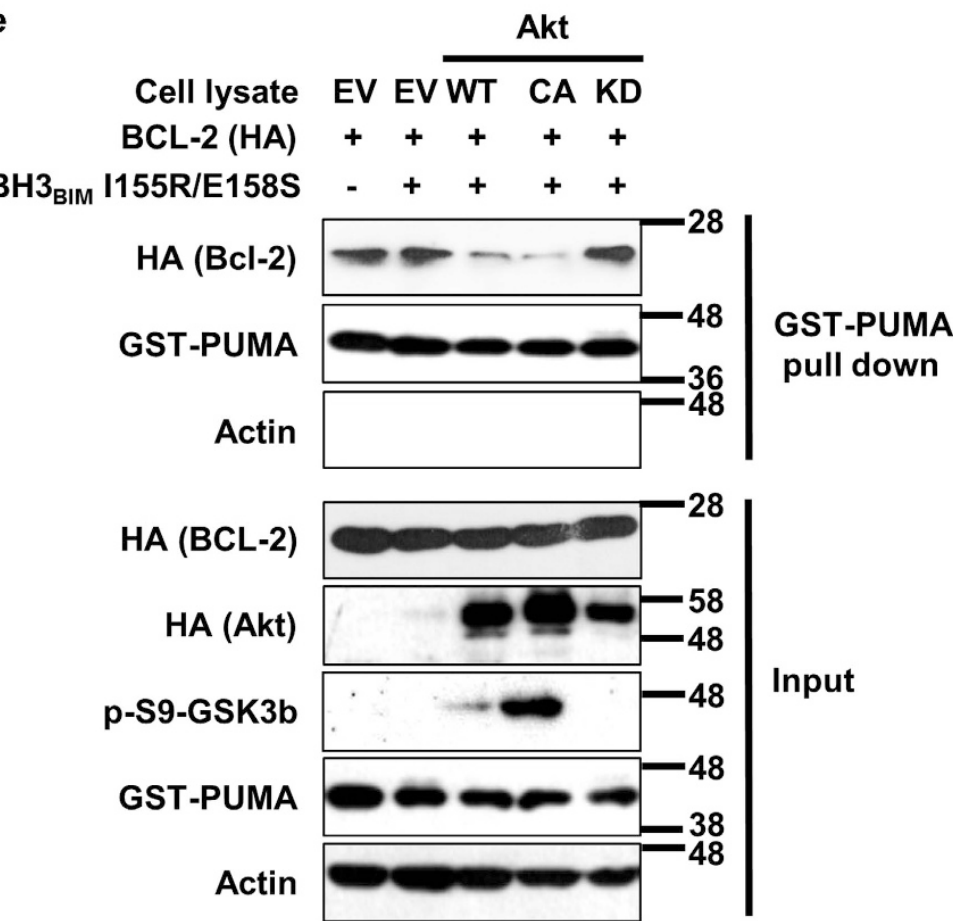

Figure 3 Phosphorylation-dependent binding of $\mathrm{BH}_{\mathrm{BIM}}(1155 \mathrm{R} / \mathrm{E} 158 \mathrm{~S})$ to $\mathrm{BCL}-2$ and $\mathrm{BCL}-\mathrm{X}_{\mathrm{L}}$. (a-d) The ITC analyses were carried out by titrating the indicated peptides $(0.2 \mathrm{mM})$ into $\mathrm{BCL}-2$ or $\mathrm{BCL}-\mathrm{X}_{\mathrm{L}}(20 \mu \mathrm{M})$. The $K_{\mathrm{D}}$ values were deduced from curve fittings of the integrated heat per mole of added ligand (insets). (e) Competition assay. The $\mathrm{BH}_{\mathrm{BIM}}(1155 \mathrm{R} / \mathrm{E} 158 \mathrm{~S})$ peptide was incubated with cell lysate containing overexpressed Akt (wild type (WT), constitutively active form (CA) or kinase-dead (KD) mutant) and HAtagged BCL-2 protein. This mixture was incubated with GST-PUMA bound to glutathione agarose resin. After washing, bound HA-tagged BCL-2 was detected by immunoblotting. Detection of $\mathrm{p}$-S9-GSK3 $\beta$ was to monitor the Akt activity. Input: used cell lysates and GST-PUMA. EV: empty vector transfection. Numbers: approximate molecular weight 
controls were not phosphorylated (Figure 2), demonstrating that Ser158 in $\mathrm{BH}_{\mathrm{BIM}}(1155 \mathrm{R} / \mathrm{E} 158 \mathrm{~S})$ is specifically phosphorylated by Akt.

To test if phosphorylated $\mathrm{BH}_{\mathrm{BIM}}(\mathrm{I155R/E} 158 \mathrm{~S})$ binds to the BCL-2 family proteins more tightly than its unphosphorylated version, we produced recombinant $B C L-2$ and $B C L-X_{L}$ proteins, and also prepared two 21-mer synthetic peptides: $\mathrm{BH}_{\mathrm{BIM}}(\mathrm{I155R} / \mathrm{E} 158 \mathrm{~S})$ and phosphorylated $\mathrm{BH}_{\mathrm{BIM}}(\mathrm{I155R} /$ $\mathrm{E} 158 \mathrm{~S})$ at Ser158, which is referred to as $\mathrm{p}-\mathrm{BH}_{\mathrm{BIM}}(\mathrm{I155R} /$ E158S) (Figure 1). Quantification of the binding affinities by isothermal titration calorimetry (ITC) showed that p-BH3 ${ }_{\mathrm{BIM}}(\mathrm{I155R/E158S)}$ interacted potently with BCL-2 and $B C L-X_{L}$ with $K_{D}$ values of 8.55 and $9.90 \mathrm{nM}$, respectively (Figures $3 a$ and $b$ ), similar to that of a longer 36-mer BIM BH3 peptide $\left(K_{\mathrm{D}}\right.$ of $\left.\sim 7 \mathrm{nM}\right) .{ }^{15}$ In contrast, the unphosphorylated $\mathrm{BH}_{\mathrm{BIM}}($ I155R/E158S) peptide exhibited much lower affinities for the two proteins ( $K_{\mathrm{D}}$ of 192 and $189 \mathrm{nM}$, respectively) (Figures 3c and d). Thus, phosphorylated Ser158 appeared to replace the role of Glu158 in the $\mathrm{BH} 3$ sequence. Furthermore, the substitution of the conserved hydrophobic lle155 seemed to be tolerated in the binding reaction, which is intriguing given the observation that an alanine substitution of the corresponding lle81 residue in a $\mathrm{BAK} B \mathrm{BH}$ peptide resulted in a significant reduction of the binding affinity for $B C L-X_{L}\left(K_{D}\right.$ value changed from 0.34 to $17 \mu \mathrm{M}){ }^{30}$

The measured binding affinities of $\mathrm{p}-\mathrm{BH} 3_{\mathrm{BIM}}(\mathrm{I155R/E158S)}$ for $B C L-2$ or $B C L-X_{L}$ are comparable to or higher than those of 36-mer $\mathrm{BH} 3$ peptides derived from BAX and BAK $\left(K_{\mathrm{D}}\right.$ of $\left.8.1-255 \mathrm{nM}\right),{ }^{15}$ suggesting that the phosphorylated $\mathrm{BH}_{\mathrm{BIM}}(\mathrm{I155R/E158S)}$ sequence, but not the unphosphorylated sequence, could displace these two apoptosis mediators from the antiapoptotic BCL-2 proteins and potentiate cell death. We indirectly tested this possibility by employing PUMA and $\mathrm{BCL}-2$, whose intermolecular interaction is tighter than that between BAX (or BAK) and BCL-2, ${ }^{15}$ to obviate complications in using full-length BAX or BAK. Recombinant human PUMA fused to GST (GST-PUMA) was produced, and HEK293 cells were prepared to transiently overexpress BCL-2 and one of the three forms of Akt: wild-type, constitutively active or kinase-dead form. Each cell lysate was incubated with $\mathrm{BH}_{\mathrm{BIM}}(\mathrm{I155R/E158S)}$ and GST-PUMA. This peptide added to the cell lysate containing the wild-type and constitutively active form of Akt abolished the binding between BCL-2 and GST-PUMA, whereas the same peptide added to the cell lysate containing the kinase-dead form of Akt did not interfere with the binding interaction (Figure 3e). The kinase activity of the Akt proteins were confirmed by examining the phosphorylation of GSK3 $\beta$, a cellular substrate of Akt (Figure 3e). Collectively, these results indicated that Akt-phosphorylated $\mathrm{BH} 3_{\mathrm{BIM}}(\mathrm{I155R} /$ E158S), and the phosphorylated peptide could compete with PUMA for binding to BCL-2, whereas the unphosphorylated peptide could not.

Structure of $B C L-X_{L}$ in a complex with $\mathrm{p}-\mathrm{BH} 3_{\mathrm{BIM}}$ (I155R/E158S). To understand the structural basis for the critical role of the Ser158 phosphorylation, we next determined the crystal structure of $B C L-X_{L}$ bound to $p-B H 3_{B I M}$ (I155R/E158S) at a 2.1-Å resolution (Table 1). The peptide binds to the $\mathrm{BH} 3-$ binding groove of $\mathrm{BCL}-\mathrm{X}_{\mathrm{L}}$ by forming an
Table 1 Data collection and structure refinement statistics

\begin{tabular}{|c|c|c|}
\hline & 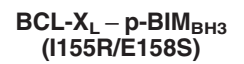 & $\begin{array}{c}\text { BCL-X } \mathrm{L}_{\mathrm{L}}-\mathrm{p}-\mathrm{BIM} \mathrm{M}_{\mathrm{BH} 3} \\
\text { (R154S/l155R/E158S) }\end{array}$ \\
\hline Space group & $P 3_{2} 21$ & $P 3$ \\
\hline $\begin{array}{l}\text { Unit cell dimensions } \\
\text { a, } b, c(\AA) \\
\text { Wavelength }(\AA) \\
\text { Resolution }(\AA) \\
R_{\text {sym }} \\
I / \sigma(I \\
\text { Completeness }(\%) \\
\text { Redundancy }\end{array}$ & $\begin{array}{c}72.9,72.9,75.5 \\
1.5418 \\
50-2.09(2.13-2.09)^{\mathrm{a}} \\
10.6(23.1) \\
34.5(8.4) \\
96.4(77.5) \\
6.3\end{array}$ & $\begin{array}{c}81.7,81.7,42.6 \\
0.97934 \\
50-1.65(1.68-1.65) \\
11.7(46.6) \\
17.3(2.1) \\
99.2(94.2) \\
6.4\end{array}$ \\
\hline $\begin{array}{l}\text { Refinement } \\
\text { Resolution }(\AA) \\
\text { Number of reflections } \\
R_{\text {work }}{ }^{c} / R_{\text {free }}\end{array}$ & $\begin{array}{c}50.0-2.1 \\
13580 \\
18.3 / 21.1\end{array}$ & $\begin{array}{l}20.0-1.7 \\
34825 \\
19.2 / 22.8\end{array}$ \\
\hline $\begin{array}{l}\text { Number of atoms } \\
\text { Protein } \\
\text { Water } \\
\text { lon }\end{array}$ & $\begin{array}{c}1364 \\
143 \\
6\end{array}$ & $\begin{array}{c}2701 \\
117 \\
6\end{array}$ \\
\hline $\begin{array}{l}\text { R.M.S deviations } \\
\text { Bond lengths }(\AA) \\
\text { Bond angles }\left(\left(^{\circ}\right)\right.\end{array}$ & $\begin{array}{l}0.005 \\
1.050\end{array}$ & $\begin{array}{l}0.007 \\
1.777\end{array}$ \\
\hline $\begin{array}{l}\text { Ramachandran plot (\%) } \\
\text { Most favored region } \\
\text { Additionally allowed region }\end{array}$ & $\begin{array}{c}95.3 \\
4.7\end{array}$ & $\begin{array}{c}99.4 \\
0.6\end{array}$ \\
\hline $\begin{array}{l}\text { Average } B \text {-values }\left(\AA^{2}\right) \\
\text { Protein } \\
\text { Peptide } \\
\text { Water }\end{array}$ & $\begin{array}{l}18.4 \\
18.8 \\
27.7\end{array}$ & $\begin{array}{l}12.3 \\
11.0 \\
19.2\end{array}$ \\
\hline
\end{tabular}

${ }^{a}$ The numbers in parentheses are statistics from the highest resolution shell. ${ }^{\mathrm{b}} R_{\mathrm{sym}}=\Sigma I_{\mathrm{obs}}-I_{\text {avg }} \mathrm{I} / I_{\mathrm{obs}}$, where $I_{\mathrm{obs}}$ is the observed intensity of individual reflection and $l_{\text {avg }}$ is average over symmetry equivalents. ${ }^{\mathrm{C}} R_{\text {work }}=\Sigma\left\|F_{\mathrm{o}}|-| F_{\mathrm{c}}\right\| / \Sigma\left|F_{\mathrm{o}}\right|$, where $\left|F_{\mathrm{o}}\right|$ and $\left|F_{\mathrm{c}}\right|$ are the observed and calculated structure factor amplitudes, respectively. $R_{\text {free }}$ was calculated with $5 \%$ of the data

amphipathic a-helix, as observed in all of the reported structures of the $\mathrm{BH} 3$ peptides bound to the antiapoptotic BCL-2 family proteins ${ }^{14,15,31}$ (Figure $4 a$ ). Since the sequence of the $\mathrm{p}-\mathrm{BH} 3_{\mathrm{BIM}}(\mathrm{I} 155 \mathrm{R} / \mathrm{E} 158 \mathrm{~S})$ peptide is highly similar to that of the $\mathrm{BH} 3$ domain of mouse BIM, the presented structure can be directly compared with the structure of BCL- $X_{L}$ bound to the $B I M_{L} B H 3$ domain. ${ }^{14}$ The $p-B H 3_{B I M}(I 155 R / E 158 S)$ peptide contains four of the five consensus residues that are highly conserved in the $\mathrm{BH} 3$ domains of the proapoptotic proteins and known to have critical roles in interacting with the antiapoptotic BCL-2 proteins. The four residues (Ile148, Leu152, Asp157 and Phe159) in the peptide are involved in the intermolecular hydrophobic or hydrophilic interactions with $B C L-X_{L}$, similar to the corresponding residues of the $\mathrm{BIM}_{\mathrm{L}} \mathrm{BH} 3$ bound to $B C L-\mathrm{X}_{\mathrm{L}}$ (not shown).

The remaining consensus residue, which corresponds to Ile155 of human BIM (lle97 of mouse BIM), is replaced by

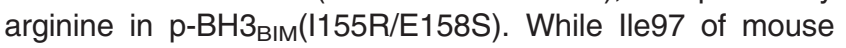
$\mathrm{BIM}$ is involved in hydrophobic interactions with Phe97 and

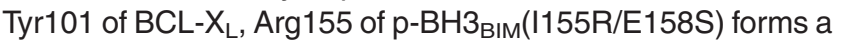
hydrophobic interaction with Tyr101 through its hydrocarbon portion, and makes an intramolecular salt bridge with Glu151 of the peptide through its guanidinium group (Figure $4 \mathrm{~b}$ ). The salt bridge is likely to increase the helical propensity of $\mathrm{p}-\mathrm{BH} 3_{\mathrm{BIM}}(\mathrm{I155R/E158S)}$ in solution and to contribute to the binding affinity of this phosphorylated peptide. 
a

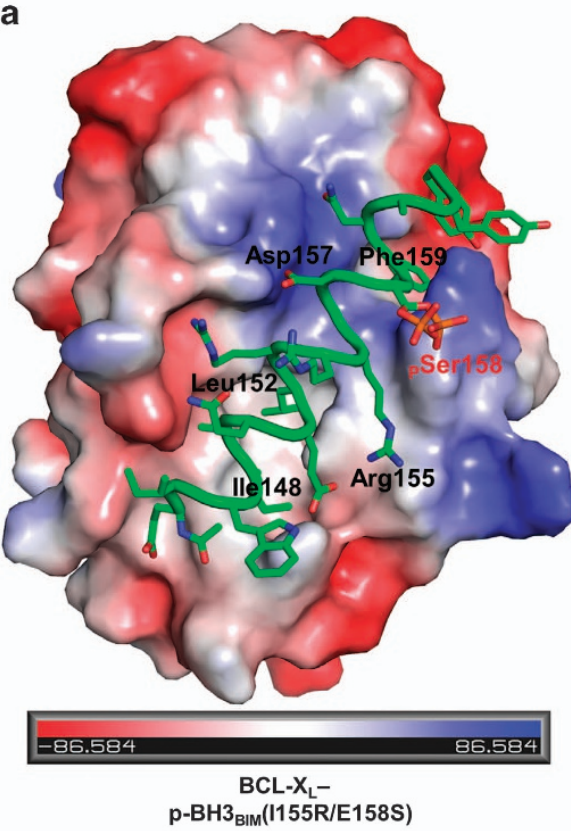

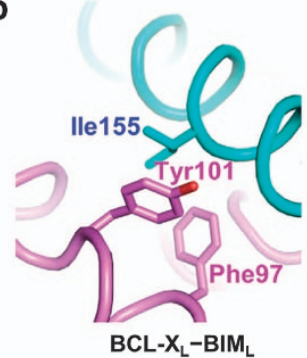

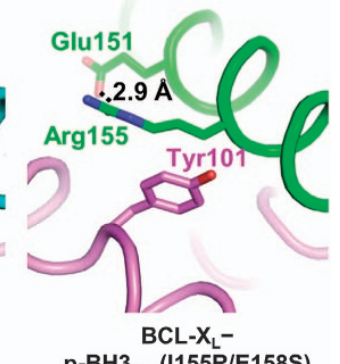

p-BH3 $3_{\text {BIM }}(I 155 R / E 158 S)$

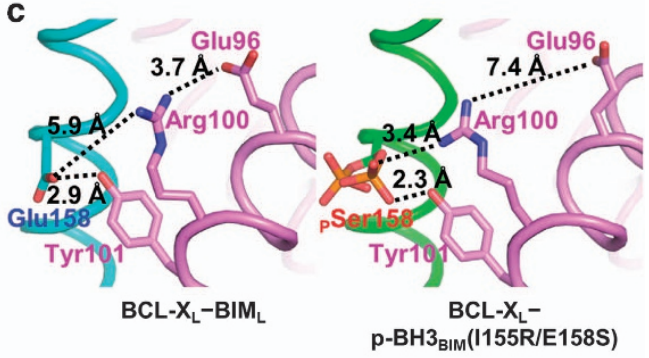

d

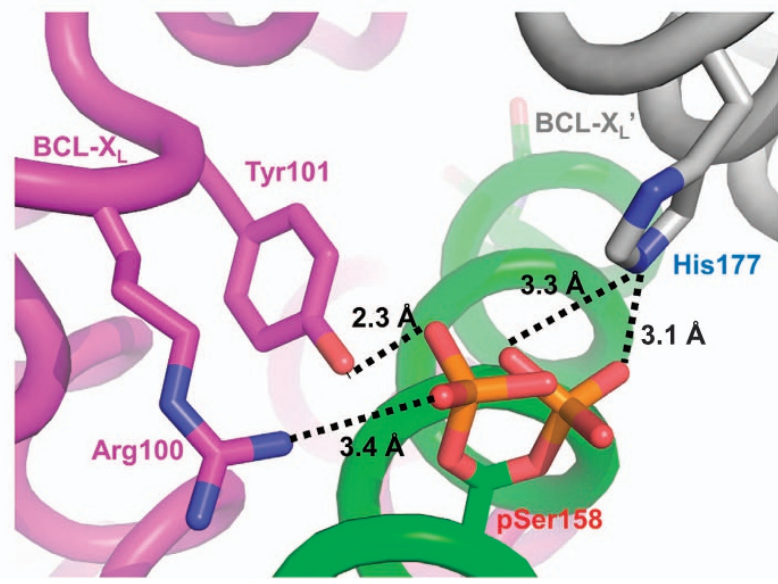

Figure 4 Structural analysis of the interaction between $B C L-X_{L}$ and p-BH3 ${ }_{B I M}(1155 R / E 158 S)$. (a) Crystal structure of the BCL- $X_{L}-p-B H 3_{B I M}(1155 R / E 158 S)$ complex. BCL-X is shown as an electrostatic surface model with the bound peptide in green. For clarity, only the residues corresponding to the five consensus $\mathrm{BH} 3$ residues (black) and the phosphoserine (red) are labeled. The values for the electrostatic potential calculated using $\mathrm{PyMOL}^{50}$ are displayed at the bottom. (b and $\mathbf{c}$ ) Side-by-side comparison of detailed intermolecular interactions of $\mathrm{BCL}-\mathrm{X}_{\mathrm{L}}$ with $\mathrm{BIM} \mathrm{M}_{\mathrm{L}}$ (left; PDB code 1PQ1) and with $\mathrm{p}-\mathrm{BH} 3_{\mathrm{BIM}}(1155 \mathrm{R} / \mathrm{E} 158 \mathrm{~S})$ (right). $\mathrm{BCL}-\mathrm{X}_{\mathrm{L}}$ is in violet, and the $\mathrm{BH} 3$ helices are in cyan or green. (b) lle155 contributing to the hydrophobic interactions (left) is substituted by arginine (right). (c) Phosphorylated Ser158 on the peptide is involved in electrostatic interactions with $\mathrm{BCL}-\mathrm{X}_{\mathrm{L}}$ (right). For comparison, the numbering of BIM residues is according to that of human $\mathrm{BIM}_{\mathrm{L}}$. (d) Dual conformations of phosphorylated Ser158. The phosphoryl group of p-BH3 $3_{\text {BIM }}(155 R / E 158 S)$ interacts with Arg100 and Tyr101 of BCL- $X_{L}$ within the complex or with His177 of the neighboring BCL- $X_{L}\left(B C L-X_{L}^{\prime}\right)$ in the crystal

Notably, the phosphate group attached to Ser158 has a dual conformation (Figures 4c right and d). In one conformation, it interacts with the guanidinium group of Arg100 and the hydroxyl group of Tyr101 of BCL-X $X_{L}$, where Arg100 is distantly

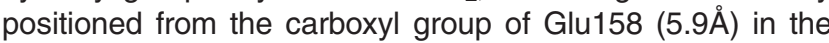
structure of the $B C L-X_{L}-B I M_{L} B H 3$ complex $^{14}$ (Figure 4c left). In the other conformation, however, the phosphate group is

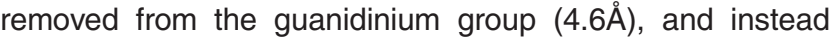
interacts with His 177 of a symmetry-related BCL- $X_{L}$ molecule (3.1 $\AA$ ) (Figure $4 d$ ). Therefore, the observed conformation of phosphorylated Ser158 in the crystalline state would be different from the conformation of this residue in solution.
Structure of BCL- $\mathrm{X}_{\mathrm{L}}$ in complex with the $\mathrm{p}-\mathrm{BH} 3_{\mathrm{BIM}}(\mathrm{R} 154 \mathrm{~S} /$ I155R/E158S) peptide. To remove the crystal packing interaction of phosphorylated Ser158, we prepared another peptide, referred to as $\mathrm{p}-\mathrm{BH} 3_{\mathrm{BIM}}(\mathrm{R} 154 \mathrm{~S} / \mathrm{I55R} / \mathrm{E} 158 \mathrm{~S})$, which contains an additional substitution of R154S in addition to the 1155R and E158S substitutions (Figure 1). Arg154 was chosen for the substitution, as this residue in $\mathrm{p}-\mathrm{BH}_{\mathrm{BIM}}(\mathrm{I155R/E158S)}$ was engaged in a crystal packing interaction with a symmetry mate (Supplementary Figure S1). In an ITC analysis, p-BH3 ${ }_{\mathrm{BIM}}(\mathrm{R} 154 \mathrm{~S} / \mathrm{I} 155 \mathrm{R} / \mathrm{E} 158 \mathrm{~S})$ exhibited slightly lower affinity for BCL- $X_{L}\left(K_{D}=\sim 40 \mathrm{nM}\right)$ compared with $\mathrm{p}-\mathrm{BH} 3_{\mathrm{BIM}}(\mathrm{I155R/E158S)}$ (Supplementary Figure S2). 

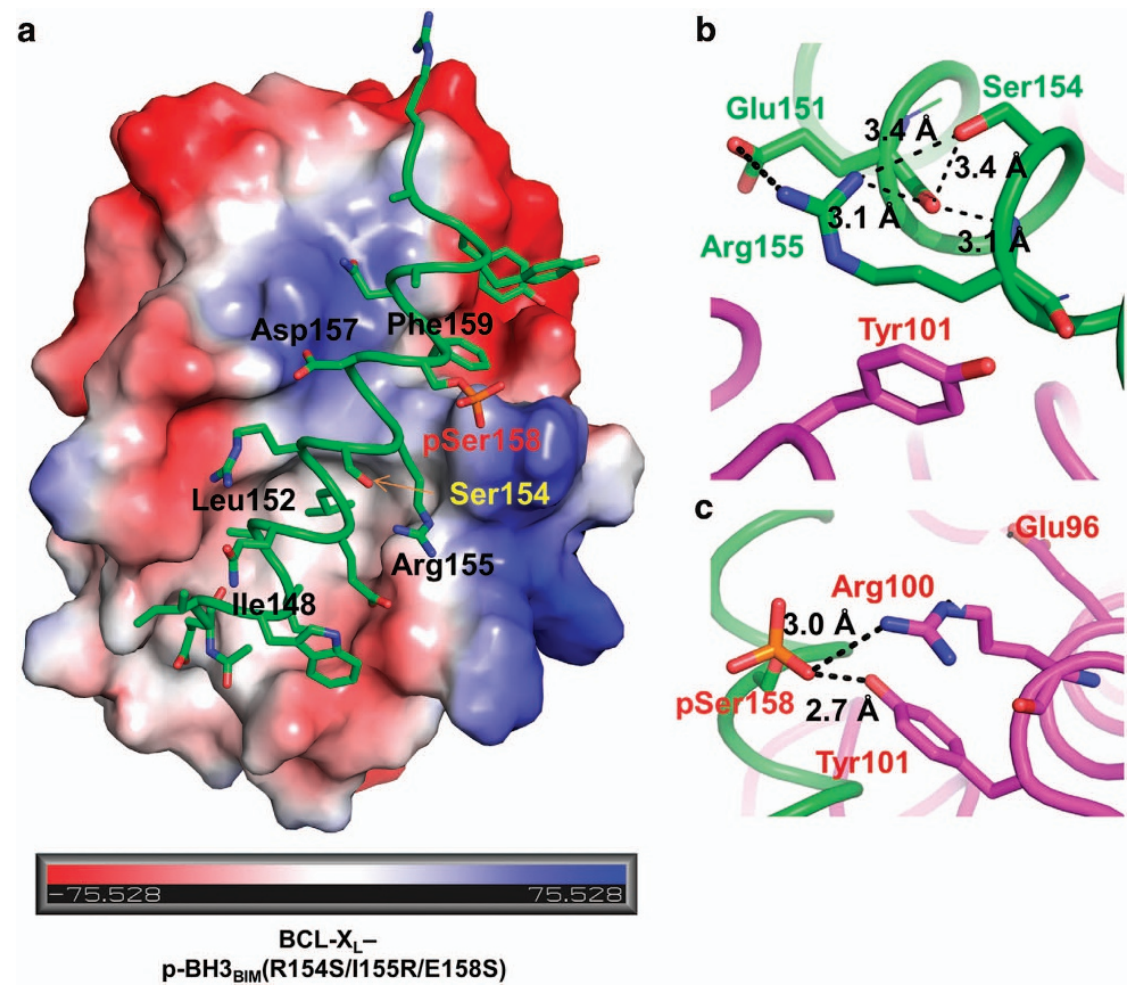

Figure 5 Structural analysis of the interaction between $B C L-X_{L}$ and p-BH3 $3_{B I M}(R 154 S / 155 R / E 158 S)$. (a) Crystal structure of the BCL-X $X_{L}-p-B H 3_{B I M}(R 154 S / 1155 R / E 158 S)$ complex. BCL- $X_{L}$ is shown as an electrostatic surface model with the bound peptide in green. The electrostatic potential is shown at the bottom. (b) Detailed interactions of the $\operatorname{Arg} 155$ of $\mathrm{p}-\mathrm{BH} 3_{\mathrm{BIM}}(\mathrm{R} 154 \mathrm{~S} / 1$ 155R/E158S) in the complex. Polar interactions are indicated by dotted lines with the distances noted. The aliphatic chain of Arg155 has a hydrophobic interaction with the Tyr101 of BCL-X. (c) Detailed phosphoserine-mediated intermolecular interactions

Subsequently, we obtained crystals of BCL- $X_{L}$ bound to this peptide in a different crystal form, and determined its structure at a $1.7 \AA$ resolution (Figure $5 \mathrm{a}$ and Table 1). In this crystal form, the asymmetric unit contained two copies of the complexes that exhibit nearly identical conformations (rmsd $=0.063 \AA$ between $143 \mathrm{C} a$ atoms; Supplementary Figure S3). Importantly, phosphorylated Ser158 in this peptide was not involved in the crystal packing interactions. The intermolecular interactions between BCL- $X_{L}$ and the peptide are mostly similar to those observed in the $B C L-X_{L}-p-B H 3_{B I M}(1155 R / E 158 S)$ structure (Figure 5b). In particular, phosphorylated Ser158 is in a single conformation and makes intermolecular interactions with Tyr101 and $\operatorname{Arg} 100$ of $\mathrm{BCL}-\mathrm{X}_{\mathrm{L}}$, which is likely to recapitulate the interactions in solution (Figure 5c). Together, the presented structures explain the significant enhancement of the binding affinity upon phosphorylation of Ser158 in the designed $\mathrm{BH}_{\mathrm{BIM}}(1155 \mathrm{R} / \mathrm{E} 158 \mathrm{~S})$ peptide.

Akt-dependent cytotoxic activity of the designed $\mathrm{BH}_{\mathrm{BIM}}$ peptide. Next, we tested whether the $\mathrm{BH} 3_{\mathrm{BIM}}($ (I155R/E158S) peptide exhibits cytotoxic activity. For intracellular delivery, $\mathrm{BH}_{\mathrm{BIM}}(1155 \mathrm{R} / \mathrm{E} 158 \mathrm{~S})$ was fused to the C-terminus of the cell penetration peptide (CPP) derived from HIV Tat (Figure 1). PC3 and HCT116 cells were treated with the CPP-BH3 ${ }_{\text {BIM }}($ I155R/E158S) peptide, and the MTT assay was performed. PC3 cells, which are derived from prostate cancer cells, exhibit a significantly elevated Akt activity due to the loss of PTEN, a negative regulator of $A k t,{ }^{32,33}$ whereas the colon cancer-derived HCT116 cells exhibit a normal level of Akt activity. Seventy-two hours after the treatment with the fusion peptide, a strong cytotoxic activity was observed in the PC3 cells, but not in the HCT116 cells (Figure 6a). Immunofluorescence analysis suggested that the PC3 cells underwent apoptotic cell death (Figure 6b). Cytochrome $c$ diffused in the cytoplasm and gradually accumulated in the nucleus, which is known to occur during apoptosis. ${ }^{34}$ In contrast, HCT116 retained the puncta staining pattern under the same treatment (Figure 6b). We then measured the activity of Akt by examining the phosphorylation state of itself and its substrate GSK3 $\beta$. The CPP-BH3 $3_{\text {BIM }}(1155 R / E 158 S)$ peptide reduced the phosphorylation of GSK3 $\beta$, but not Akt itself (Figure 6c), indicating that this peptide could have acted as a substrate of Akt. To elaborate this observation, we examined the effect of the fusion peptide in three different human lung cancer cell lines. The PTEN-silenced $\mathrm{H} 1299$ cell lines exhibited sensitivity to the peptide, and the A549 cell line, which possesses a K-Ras mutation, showed a moderate response (Figure $6 \mathrm{~d}$ ). In contrast, the $\mathrm{H} 23$ cell line, which is derived from lung cancer cells with wild-type K-Ras and normal level of Akt activity, did not respond to this peptide, suggesting that the CPP-BH3 $3_{\mathrm{BIM}}(1155 \mathrm{R} / \mathrm{E} 158 \mathrm{~S})$-induced cell death might depend on the Akt activity. We then assessed the effect of the Akt activity by ectopically expressing wild-type Akt (Akt-WT), constitutively active Akt (myristoylated Akt; AktMyr) or kinase-dead-Akt (Akt-KD). Both Akt-WT and Akt-Myr 

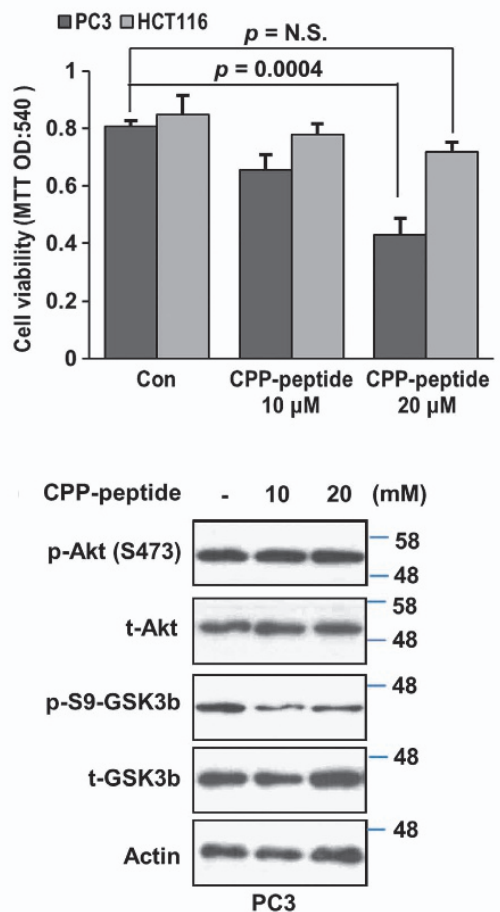

e
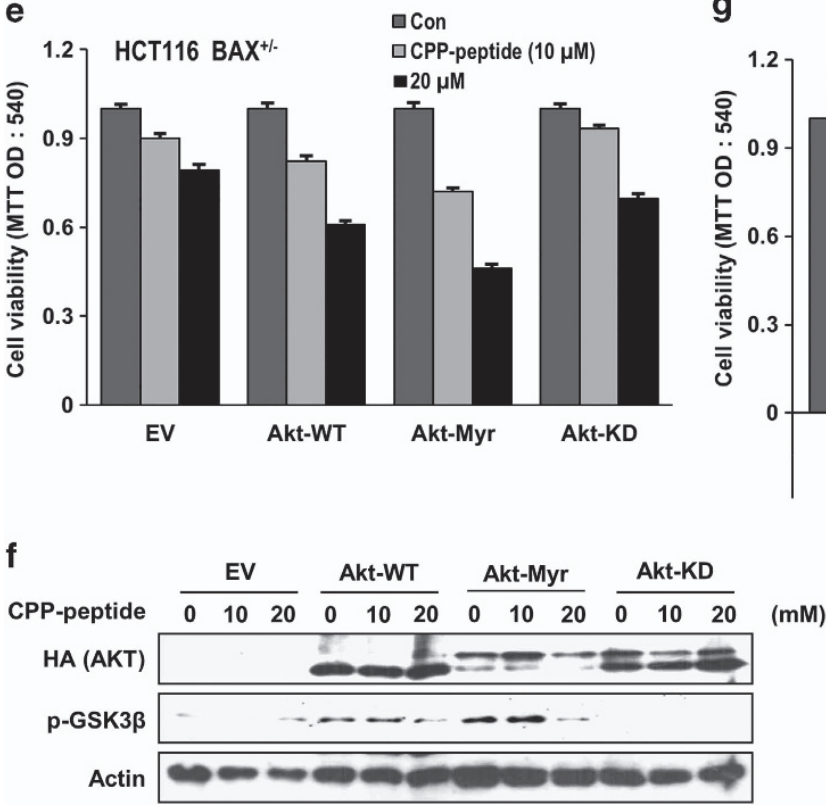

b

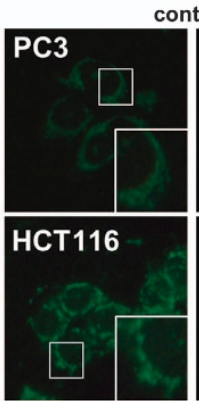

control
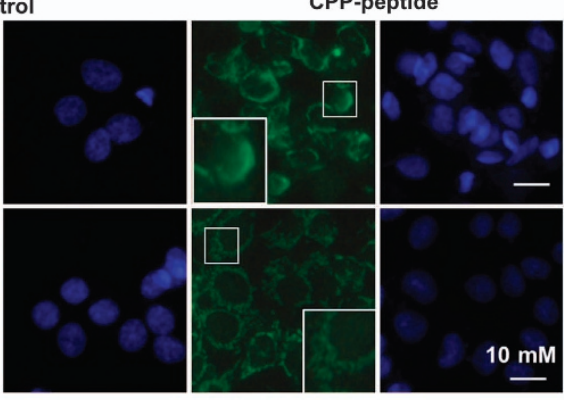

d

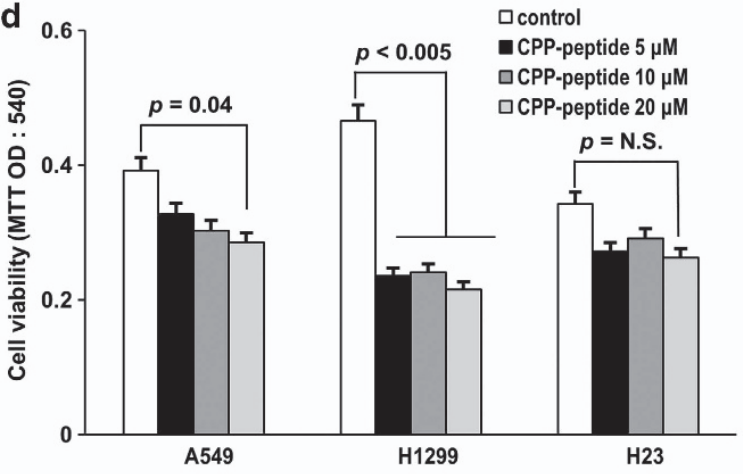

g

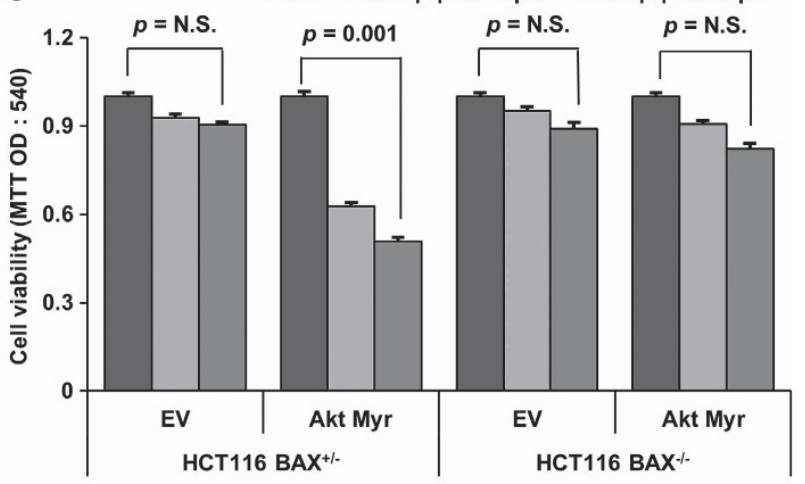

Figure 6 CPP-fused BH3 $3_{\mathrm{BIM}}(1155 \mathrm{R} / \mathrm{E} 158 \mathrm{~S})$ peptide induces death of PC3 cells. (a) Cell viability evaluated by the MTT assay $72 \mathrm{~h}$ after treatment of the peptide $(0,10$ or $20 \mu \mathrm{M})$. N.S indicates non-significance. Error bars indicate S.D. $(n=3)$. (b) The immunofluorescence images of PC3 and HCT116 cells treated with 20- $\mu \mathrm{M}$ CPP-BH3 $\mathrm{BIM}(1155 \mathrm{R} / \mathrm{E} 158 \mathrm{~S})$. Cytochrome $c$ (green) was detected by anti-cytochrome $c$ antibody and FITC-conjugated secondary antibody, and the nucleus was stained by DAPI. The large boxes are the enlargement of the small boxes, highlighting the cytochrome $c$ staining. (c) Western blot (WB) analysis to examine the effect of CPP-BH3 $3_{\mathrm{BIM}}(1155 \mathrm{R} / \mathrm{E} 158 \mathrm{~S})$ on the phosphorylation of Akt (at Ser473) and GSK3 $\beta$ (at Ser9). PC3 cells were incubated with the peptide for $6 \mathrm{~h}$ at the indicated concentration. t-Akt and t-GSK3 $\beta$ stand for total Akt and GSK3 $\beta$, respectively. (d) MTT assay to examine the cytotoxic effect of CPP-BH3 $3_{\text {BIM }}(1155 \mathrm{R} / \mathrm{E} 158 \mathrm{~S})$ on lung cancer cell lines. The viability of $P T E N$-silenced $\mathrm{H} 1299$ cells was

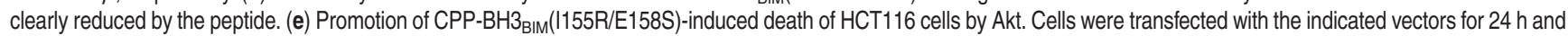
incubated with the peptide for $72 \mathrm{~h}$. Cell death was promoted by Akt-WT and Akt-Myr, but not by Akt-KD. (f) Phosphorylation of GSK3 $\beta$ (p-GSK3 $\beta$ ) by Akt-WT and Akt-Myr, but not by Akt-KD. Cells were harvested for WB after incubation with CPP-peptide for $6 \mathrm{~h}$. Actin was used for loading control. (g) CPP-BH3 $3_{\text {BIM }}\left(1155 \mathrm{R} / \mathrm{E}_{158 \mathrm{~S})}\right.$ induced apoptosis in a BAX-dependent manner. HCT116 cells and its isogenic BAX-1- cells were transfected with Akt-Myr for $24 \mathrm{~h}$ and incubated with the peptide at the indicated concentration for $72 \mathrm{~h}$. HCT116 $B A X^{+/-}$cells, but not HCT116 $B A X^{-1-}$ cells, were affected by the peptide 
promoted death of HCT116 cells, whereas Akt-KD did not show an additive effect (Figure 6e). The kinase activities of the three Akt versions were confirmed by examining GSK3 $\beta$

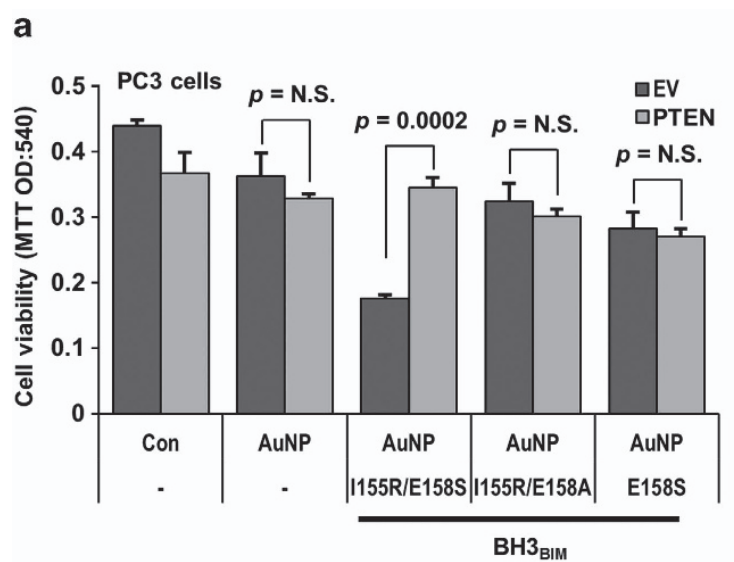

phosphorylation (Figures $6 f$ and p-GSK3 $\beta$ ). To know whether CPP-BH3 ${ }_{\mathrm{BIM}}($ I155R/E158S)-induced cell death might depend on BAX, the HCT116 BAX ${ }^{+/-}$and the HCT116 BAX ${ }^{-1-}$ cell

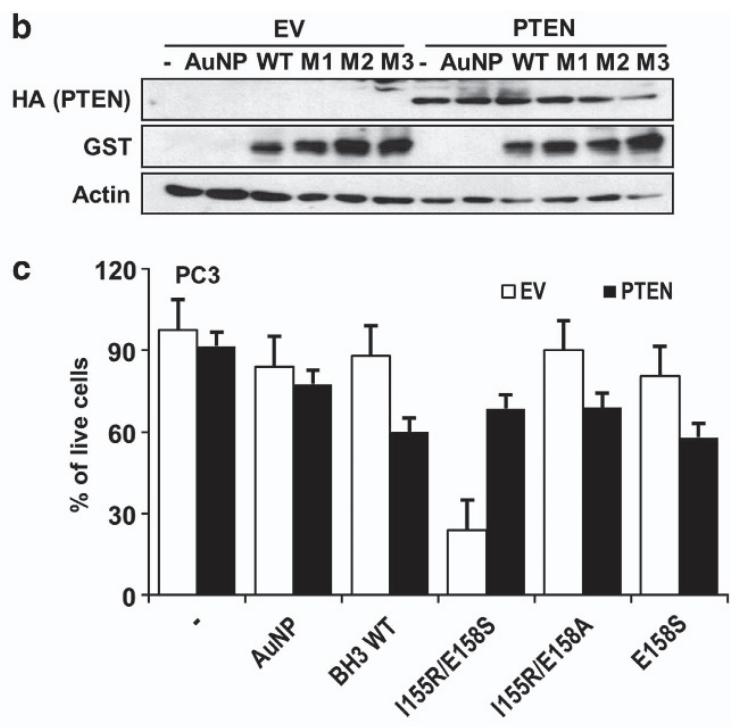

d
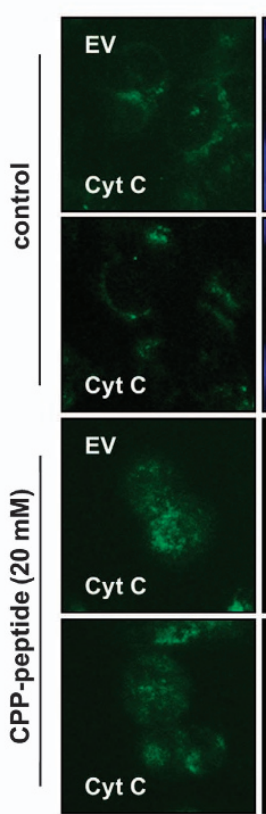
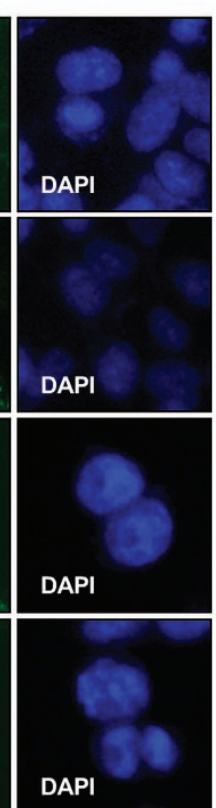

e

CPP-peptide $(\mu \mathrm{M})$

Cytochrome $c$

p-S9-GSK3 $\beta$

t-GSK3 $\beta$

Lamin A/C

PTEN
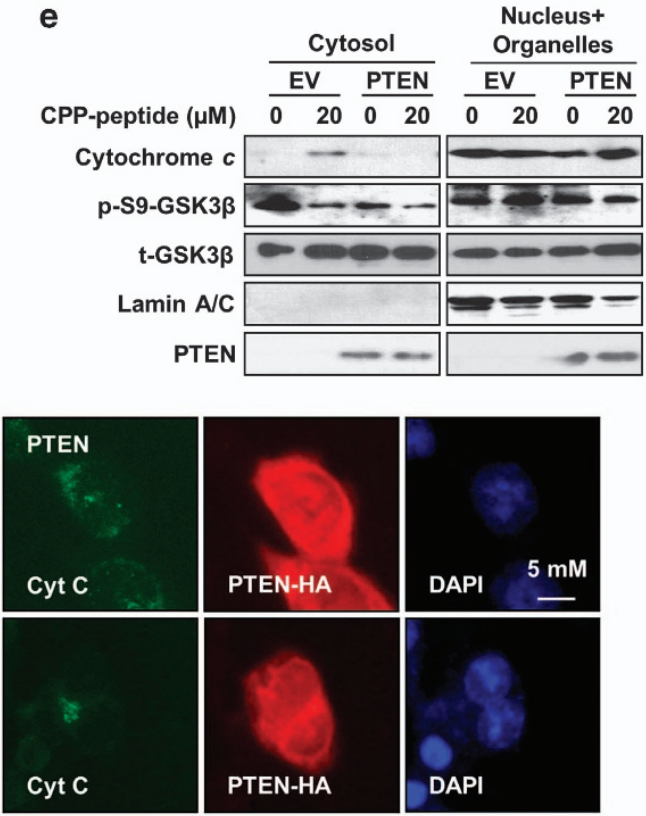

f

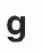

g

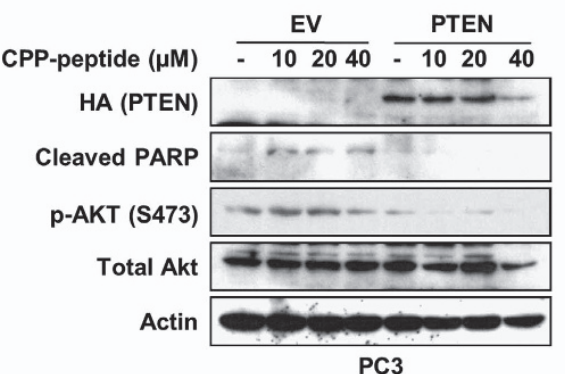


lines were transfected with an expression vector encoding $A K T-M y r$ and the cells were treated with the peptide. Notably, the $B A X^{+/-}$cells, but not the $B A X^{-1-}$ cells, were sensitized to the peptide (Figure $6 \mathrm{~g}$ ), indicating that the CPP$\mathrm{BH}_{\mathrm{BIM}}(\mathrm{I155R/E158S})$ peptide induced intrinsic apoptotic cell death via $B A X$. The survival of the $B A X^{-1-}$ cells despite the CPP-BH3 ${ }_{\mathrm{BIM}}(\mathrm{I155R/E158S)}$ treatment could be explained by an observation that the designed peptide only weakly binds to MCL-1 (not shown), which is a major inhibitor of BAK. ${ }^{35}$ Presumably, both MCL-1 and BAK are expressed in these cells. ${ }^{36}$

\section{PTEN-dependent cytotoxic effect of the designed}

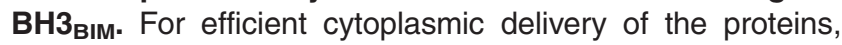
we applied a novel technique of using gold nanoparticles (AuNPs) coated with anti-GST DNA aptamers. ${ }^{37}$ To apply this technique, GST-fused the $\mathrm{BH}_{\mathrm{BIM}}$ peptides were produced and incubated with AuNPs coated with anti-GST DNA aptamer. We observed that GST-BH3 BIM $_{\text {(I155R/E158S) }}$ efficiently killed PC3 cells (Figure 7a). In contrast, the other variants, GST-BH3 $3_{\mathrm{BIM}}(\mathrm{E} 158 \mathrm{~S})$ and GST-BH3 $3_{\mathrm{BIM}}(\mathrm{I155R} /$ E158A), did not exhibit a cell-killing effect (Figure 7a), presumably because these two peptides lack either the Akt recognition sequence or a site for phosphorylation by Akt. Intriguingly, when the PTEN gene was introduced into PC3 cells by transfection, the cell-killing effect of GST-BH3 ${ }_{\mathrm{BIM}}$ (I155R/E158S) was significantly reduced (Figure 7a). We confirmed that GST-BH3 $3_{\mathrm{BIM}}$-coated AuNPs were effectively incorporated into the cells (Figure $7 \mathrm{~b}$ ). To confirm the cytotoxic effect of each protein, we performed the trypan blue dye exclusion assay and counted viable cells. Consistent with the MTT assay described above, the AuNPs coated with GST-BH3 ${ }_{\text {BIM }}($ I155R/E158S) clearly reduced the viability of $\mathrm{PC} 3$ cells (Figure 7c). In a control experiment, $\mathrm{BH}_{\mathrm{BIM}}(\mathrm{I155R/E158S)}$ and its variants did not alter the expression of proapoptotic proteins such as BAX or PUMA (Supplementary Figure S4).

To examine the effect of PTEN that is frequently deleted or mutated in various kinds of cancers, we ectopically expressed PTEN in PC3 cells and examined cytochrome $c$ release. In immunostaining and cell fractionation analyses, cytochrome $c$ release was blocked in the cells transfected with a PTENexpressing vector, in contrast with the cells transfected with an empty vector (Figures 7d and e; Supplementary Figure S5). In fact, production of cleaved PARP, a well-known caspase 3 substrate, was abolished by PTEN transfection (Figure 7f). These results imply that $\mathrm{BH} 3_{\mathrm{BIM}}(1155 \mathrm{R} / \mathrm{E} 158 \mathrm{~S})$ might be used as apoptosis inducer in PTEN-mutated cancer cells. In contrast with PC3 cells, the viability of HEK293 cells was not affected by the GST-BH3 $3_{\mathrm{BIM}}$-coated AuNPs, which might be ascribed to the normal activity of Akt in HEK293 cells (Figure 7g). Indeed, the AuNP-protein and the CPP-peptide slightly increased cell viability without a statistical significance (Supplementary Figure S6), indicating that the designed peptide is not harmful to untransformed cells. Together, these results demonstrate that it is possible to convert the hyperactivity of Akt in cancer cells into a death signal.

\section{Discussion}

Hyperactivation of Akt is one of the most common molecular perturbations, frequently found in many types of cancers, including glioma, non-small cell lung cancer (NSCLC), ovarian cancer and prostate cancer, ${ }^{28,38-40}$ indicating that Akt is an attractive target for cancer therapy. Several Akt inhibitors have been developed and clinically trialed. ${ }^{39}$ However, these inhibitors seem to inevitably accompany side effects, because Akt is also important for the survival of normal cells. We described a new concept and experimental support of converting a cell-survival signal into a cell-killing apoptotic signal with an aim of killing cancer cells without affecting normal cells. These two paradoxical pathways are connected by a peptide designed to harbor the Akt recognition sequence on the potently apoptotic BIM BH3 domain. The peptide was phosphorylated by Akt as we intended, and the phosphorylated peptide interfered with the binding between BCL-2 and the PUMA BH3 domain, most likely because of its potent binding affinity for BCL-2, whereas the weakly interacting unphosphorylated peptide failed to do so. The crystal structures demonstrated how phosphorylation of Ser158 in the peptide significantly enhances the binding affinity of the peptide for BCL-X $X_{L}$. Remarkably, the peptide killed cancer cells exhibiting uncontrolled Akt activity, while cells bearing the normal Akt activity were unaffected.

The mode of action of the designed peptide is analogous to that of the tumor suppressor, ARF. The ARF protein leads to p53-dependent cell cycle arrest and apoptosis in response to sustained mitogenic signaling from Myc and Ras. ${ }^{41}$ The arf gene is deleted or silenced in numerous cancers, highlighting the important role of ARF as a tumor suppressor. ${ }^{42}$ Like ARF, the designed peptide might block tumor progression. We note that the RxRxxS/T motif can also be phosphorylated by RSK and S6K, which promote cell proliferation and growth. ${ }^{43}$ In certain cancer cells, the designed peptide is likely to be phosphorylated by all of the three kinases, which trigger the

\footnotetext{
Figure 7 The $\mathrm{BH}_{\mathrm{BIM}}(1155 \mathrm{R} / \mathrm{E} 158 \mathrm{~S})$ sequence induces phosphorylation-dependent cell death. (a) Cell viability by the MTT assay. One day after transfection of PC3 cells with an empty vector (EV) or a PTEN-expressing vector (PTEN), cells were treated for $12 \mathrm{~h}$ with AuNP-anti-GST DNA aptamer composite coated with the indicated BH3 $3_{\mathrm{BIM}}$ peptide fused to GST $(5 \mu \mathrm{M})$. (b) Intracellular delivery of the GST-fused peptides. Cells were washed with PBS three times to remove proteins attached to the plasma membrane. M1 stands for $\mathrm{BH}_{\mathrm{BIM}}(\mathrm{E} 158 \mathrm{~S}), \mathrm{M} 2$ for $\mathrm{BH} 3_{\mathrm{BIM}}(1155 \mathrm{R} / \mathrm{E} 158 \mathrm{~A})$, and $\mathrm{M} 3$ for $\mathrm{BH}_{\mathrm{BIM}}$ (I155R/E158S). (c) Cell viability by trypan blue dye exclusion assay. To confirm the effect in (a), cells were incubated with indicated materials for $24 \mathrm{~h}$ and stained with trypan blue for $10 \mathrm{~min}$. Percent of live cells were determined by average of $200 \mathrm{cells}$ in three independent experiments. (d) Immunostaining of cytochrome $c$ in PC3 cells. Cells were transfected (EV or PTEN), and incubated with the CPP-BH3 $3_{\text {BIM }}$ (1155R/E158S) peptide (CPP-peptide) for $48 \mathrm{~h}$. Cytoplasmic puncta staining pattern was observed with PC3 cell expressing PTEN (red). In contrast, a diffused nuclear pattern was observed with EV-transfected cells.

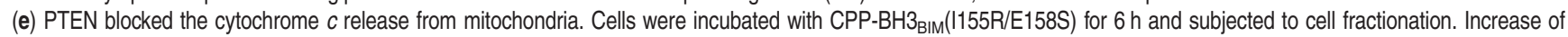
cytoplasmic cytochrome $c$ by CPP-BH3 ${ }_{\text {BIM }}(1155 R / E 158 S)$ was obviously blocked by PTEN expression. Reduction of p-S9-GSK3 $\beta$ indicated competition of S9-GSK3 $\beta$ with the peptide for phosphorylation by PTEN. (f) PTEN also blocked PARP cleavage, an indicator of caspase activation. (g) HEK293 cells were treated in the same way as in (a). Viable cells were evaluated $48 \mathrm{~h}$ after the treatment by the MTT assay. Error bars indicate the S.D. $(n=3)$
} 
core Akt-RSK-S6K signaling pathways that are activated at the downstream of protooncogenic receptor protein kinases. ${ }^{43}$

The techniques for the intracellular delivery of proteins and peptides are under active development. Combined with effective techniques, the peptide or protein versions of the designed BIM $\mathrm{BH} 3$ variant might be developed into an anticancer drug with greatly reduced side effects. Other deregulated kinases leading to uncontrolled cell growth may also be targeted by embedding different recognition sequences in an apoptogenic BH3 sequence. In conclusion, our results represent a conceptual advance in designing peptide or protein-based cancer therapeutics that are potentiated in cancer cells, but remain dormant in normal cells.

\section{Materials and Methods \\ Plasmids. The procedures for the expression of mouse BCL- $X_{L}$ was described previously. ${ }^{15}$ In brief, a DNA fragment coding for mouse BCL- $X_{L}$ (residues 1-44 and 85-196) was cloned into pProEX-HTa (Invitrogen, Carlsbad, CA, USA). To express the $\mathrm{BH}_{\mathrm{BIM}}$ peptide and its variants as a GST-fusion protein in Escherichia coli, chemically synthesized DNA fragments encoding human BIM BH3 (residues 145- 165 with appropriate mutations; BIONEER, Daejeon, South Korea) were inserted into the pGEX-TEV vector (a modified vector derived from pGEX-4T1) using the EcoRI and Hindll sites. I153R and E156S mutations were introduced into the vector by site-directed mutagenesis methods based on the overlapping PCR method. DNA fragments encoding full-length human PUMA was amplified from a human CDNA library (Life Technologies, Carlsbad, CA, USA) by a standard PCR protocol, and inserted into the pGEX-TEV vector using the EcoRI and Hindll sites. Akt and PTEN expression vectors were purchased from Addgene (Cambridge, MA, USA; PTEN, Akt-WT and Akt-Myr deposited by Dr William Sellers; Akt-KD (K179M) deposited by Dr Mien-Chie Hung)}

Expression and purification of recombinant proteins. Mouse BCL$X_{L}$ was purified as reported. ${ }^{15}$ In brief, the protein was expressed in the E. coli BL21 (DE3) strain (Novagen, Darmstadt, Germany) at $18^{\circ} \mathrm{C}$ overnight and purified by using a Ni-NTA column (Qiagen, Venlo, Limburg, Nederland) and a HiTrap Q anion exchange column (GE Healthcare, Little Chalfont, Buckinghamshire, UK). The $\mathrm{N}$-terminal hexahistidine tag was cleaved with TEV protease after a Ni-NTA column purification step. GST-fused $\mathrm{BH}_{\mathrm{BIM}}$ variants and mouse PUMA were expressed in $E$. coli and purified with the GST-binding agarose resin (Qiagen) equilibrated with 20-mM Tris buffer ( $\mathrm{pH} 8.0$ ) containing 150-mM NaCl and 2-mM $\beta$-mercaptoethanol. HA-tagged mouse BCL-2 was expressed from the pCDNA5/FRT/TO vector in HEK293 cells.

Peptides. The synthetic 21-mer peptides, $\mathrm{BH}_{\mathrm{BIM}}(1155 \mathrm{R} / \mathrm{E} 158 \mathrm{~S}), \mathrm{BH}_{\mathrm{BIM}}$ (R154S/1155R/E158S), p-BH3 ${ }_{\text {BIM }}$ (I155R/E158S), p-BH3 and the CPP-fused BH3BIM(R154S/l155R/E158S) peptide (YGRRARRRARR EIWIAQELRRRGDSFNAYYAR; with the underline indicating the CPP residues) were purchased from Peptron (Daejeon, South Korea). All peptides were modified to have an acetylated amino terminus and an amidated carboxyl terminus.

Crystallization and structural determination. Purified $B C L-X_{L}$ $(4 \mathrm{mg} / \mathrm{ml})$ in a buffer consisting of $20-\mathrm{mM}$ Tris- $\mathrm{HCl}(\mathrm{pH} 8.0), 50-\mathrm{mM} \mathrm{NaCl}$ and 1-mM dithiothreitol was mixed with $\mathrm{p}-\mathrm{BH} 3_{\mathrm{BIM}}(1155 \mathrm{R} / \mathrm{E} 158 \mathrm{~S})$ at a molar ratio of $1: 3$. The crystals of the resulting complex were obtained by the hanging-drop vapor diffusion method at $24^{\circ} \mathrm{C}$ by mixing and equilibrating $1 \mu \mathrm{l}$ of the protein solution, $1 \mu \mathrm{l}$ of a precipitant solution containing $0.1-\mathrm{M}$ sodium acetate $(\mathrm{pH} 4.8$ ) and 3.0-M sodium chloride and $0.5 \mu \mathrm{l}$ of $20 \% \mathrm{v} / \mathrm{v}$ 1,1,1,3,3,3-hexafluoro-2-propanol. Before data collection, the crystals were immersed briefly in a cryoprotectant solution, which was the reservoir solution containing additional $15 \%$ glycerol. A diffraction data set at 2.1 $\AA$ was collected on R-Axis IV++ (Rigaku, Tokyo, Japan) at the Korea Research Institute of Bioscience and Biotechnology, Korea. The data set was processed using the program suit HKL2000. ${ }^{44}$ The structure was determined by the molecular replacement method with the CCP4 version of MolRep ${ }^{45}$ using the structure of the BAD BH3 peptide-bound BCL- $X_{L}^{46}$ as a search model. Subsequently, model building and refinement were carried out using the $\mathrm{COOT}^{47}$ and $\mathrm{CNS}^{48}$ programs. The final model did not include residues $32-44$ of $B C L-X_{L}$ and the last two C-terminal residues of $\mathrm{p}-\mathrm{BH} 3_{\mathrm{BIM}}(1155 \mathrm{R} / \mathrm{E} 158 \mathrm{~S})$ whose electron densities were not observed or very weak.

For crystallization of $\mathrm{BCL}-\mathrm{X}_{\mathrm{L}}$ bound to $\mathrm{p}-\mathrm{BH} 3_{\mathrm{BIM}}(\mathrm{R} 154 \mathrm{~S} / \mathrm{l155R} / \mathrm{E} 158 \mathrm{~S})$, the purified BCL- $X_{L}$ sample $(18.5 \mathrm{mg} / \mathrm{ml})$ was mixed with $\mathrm{p}-\mathrm{BH} 3_{\mathrm{BIM}}(\mathrm{R} 154 \mathrm{~S} / 1155 \mathrm{R} /$ E158S) at a molar ratio of $1: 2$. The crystals of the resulting complex grew in a precipitant solution containing $0.1-\mathrm{M}$ sodium acetate $(\mathrm{pH} 4.6), 0.01-\mathrm{M}$ calcium chloride and 15\% v/v 2-methyl-2,4-pentanediol. Before data collection, the crystals were immersed briefly in a cryoprotectant solution containing additional $20 \%$ glycerol. A diffraction data set at $1.65 \AA$ was collected at the $5 \mathrm{C}$ beamline of the Pohang Accelerator Laboratory (PAL, Pohang, South Korea) using a QUANTUM 270 CCD detector (ADSC). The data set was processed using the program suit HKL2000. ${ }^{44}$ The structure was determined by the molecular replacement method with the CCP4 version of MolRep ${ }^{45}$ using the structure of the $\mathrm{p}-\mathrm{BH}_{\mathrm{BIM}}(1155 \mathrm{R} / \mathrm{E} 158 \mathrm{~S})$ peptidebound $B C L-X_{L}$ as a search model. Subsequently, model building and refinement were carried out using the programs $\mathrm{COOT}^{47}$ and PHENIX. ${ }^{49}$ Figures were generated using PyMOL. ${ }^{50}$ The final model did not include residues 1 and $31-43$ of BCL-X, which are disordered in the crystal. Crystallographic data statistics are summarized in Table 1.

Isothermal titration calorimetry. All measurements were carried out at $25^{\circ} \mathrm{C}$ on a microcalorimetry system iTC200 (GE Healthcare). The BCL-2 and BCL$\mathrm{X}_{\mathrm{L}}$ samples were dialyzed against the solution containing $20 \mathrm{mM}$ Tris- $\mathrm{HCl}(\mathrm{pH} 7.5)$ and $350 \mathrm{mM} \mathrm{NaCl}$. Peptides were titrated into the proteins. Dilution enthalpies were measured in separate experiments (titrant into buffer) and subtracted from the enthalpies of the binding between the protein and the titrant. Data were analyzed using the Origin software (OriginLab Corp., Northampton, MA, USA). We did three independent experiments, which gave the similar results.

In vitro kinase assay for Akt. Each reaction mixture $(20 \mu l)$ contained recombinant protein substrate $(9 \mu \mathrm{M})$, Akt/PKBa $(0.4 \mu \mathrm{M})$ purchased from Millipore (Billerica, MA, USA), ATP $(100 \mu \mathrm{M})$, and $\left[\gamma^{-}{ }^{32} \mathrm{P}\right] \mathrm{ATP}(0.5 \mathrm{mCi} / \mathrm{ml})$ in a buffer solution containing $250 \mathrm{mM}$ Tris- $\mathrm{HCl}(\mathrm{pH} 8.0), 50 \mathrm{mM} \mathrm{MgCl}$ and $50 \mathrm{mM}$ dithiothreitol. The mixture was incubated for $1 \mathrm{~h}$ at $37^{\circ} \mathrm{C}$ and loaded onto a 15\% SDS-PAGE gel. After electrophoresis $(250 \mathrm{~V}, 37 \mathrm{~min})$, the radioactivity of the gel was detected with FLA-7000 (Fujfilm, Tokyo, Japan).

Measurement of cell viability. PC3 and HEK293 cells were incubated with the GST-BH3 ${ }_{\text {BIM }}(1155 R / E 158 S)$ protein conjugated to AuNP-anti-GST DNA aptamer composite $^{37}$ after transfection with a PTEN expression vector (pCMV Flag WTPTEN; addgene plasmid \#22231). To examine the effect of the CPP-fused $\mathrm{BH}_{\mathrm{BIM}}$ peptide on cell viability, PC3 and HCT116 cells were incubated with the peptide for 48 and $72 \mathrm{~h}$. To examine cell viability, these cells were incubated with $0.5 \mathrm{mg} / \mathrm{ml}$ of MTT solution (Calbiochem, Darmstadt, Germany) for $4 \mathrm{~h}$ at $37^{\circ} \mathrm{C}$. After removing excess solution and washing with PBS, the precipitated materials were dissolved in $200 \mathrm{ml}$ of dimethyl sulfoxide and quantified by measuring the absorbance at $540 \mathrm{~nm}$. Each experiment was performed by at least three different researchers.

Immunofluorescence staining. Cells were seeded on a cover glass and incubated with the CCP-fused $\mathrm{BH}_{\mathrm{BIM}}(1155 \mathrm{R} / \mathrm{E} 158 \mathrm{~S})$ peptide. After fixing with methanol for $30 \mathrm{~min}$, cells were incubated with blocking buffer $(0.2 \%(\mathrm{v} / \mathrm{v})$ normal human antibodies in PBS) for $1 \mathrm{~h}$. After extensive washing with PBS, they were incubated with $1 \%(\mathrm{v} / \mathrm{v})$ anti-cytochrome $c$ mouse antibody (BD, cat\# 556432) in blocking buffer for $4 \mathrm{~h}$ and subsequently with $0.2 \%$ (v/v) FITC-conjugated antimouse Ab in PBS containing anti-human antibodies for $2 \mathrm{~h}$. The nucleus was stained by DAPI. After washing with PBS, cover glasses were mounted with Vectamount (Vector Laboratories, Burlingame, CA, USA). The immunofluorescence signal was detected by fluorescence microscopy (Zeiss, Oberkochen, Germany).

Statistical analysis. Statistical significance was obtained by student's t-test.

\section{Conflict of Interest}

The authors declare no conflict of interests.

Acknowledgements. This study was supported by grants from the National Research Foundation of Korea, funded by the Ministry of Science, ICT and Future Planning (NRF-2014R1A2A1A1105028, to NCH, the Basic Science Research Program NRF-2013R1A1A2010008 to BJP and the GRL Program 2014040003 to 
BHO); the Korea Research Institute of Bioscience and Biotechnology Research Initiative Program (to BK); KAIST Future Systems Healthcare Project, Ministry of Science, ICT and Future Planning (to BHO).

1. Danial NN, Korsmeyer SJ. Cell death: critical control points. Cell 2004; 116: 205-219.

2. Tait SW, Green DR. Mitochondria and cell death: outer membrane permeabilization and beyond. Nat Rev Mol Cell Biol 2010; 11: 621-632.

3. Antignani A, Youle RJ. How do Bax and Bak lead to permeabilization of the outer mitochondrial membrane? Curr Opin Cell Biol 2006; 18: 685-689.

4. Green DR, Kroemer G. The pathophysiology of mitochondrial cell death. Science 2004; 305 626-629.

5. Certo M, Del Gaizo Moore V, Nishino M, Wei G, Korsmeyer S, Armstrong SA et al. Mitochondria primed by death signals determine cellular addiction to antiapoptotic BCL-2 family members. Cancer Cell 2006; 9: 351-365.

6. Kvansakul M, Hinds MG. The Bcl-2 family: structures, interactions and targets for drug discovery. Apoptosis 2015; 20: 136-150.

7. Kim H, Rafiuddin-Shah M, Tu HC, Jeffers JR, Zambetti GP, Hsieh JJ et al. Hierarchical regulation of mitochondrion-dependent apoptosis by BCL-2 subfamilies. Nat Cell Biol 2006; 8: 1348-1358.

8. Letai A, Bassik MC, Walensky LD, Sorcinelli MD, Weiler S, Korsmeyer SJ. Distinct BH3 domains either sensitize or activate mitochondrial apoptosis, serving as prototype cancer therapeutics. Cancer Cell 2002; 2: 183-192.

9. Kuwana T, Bouchier-Hayes L, Chipuk JE, Bonzon C, Sullivan BA, Green DR et al. $\mathrm{BH} 3$ domains of $\mathrm{BH} 3-$ only proteins differentially regulate Bax-mediated mitochondrial membrane permeabilization both directly and indirectly. Mol Cell 2005; 17: 525-535.

10. Muchmore SW, Sattler M, Liang H, Meadows RP, Harlan JE, Yoon HS et al. X-ray and NMR structure of human Bcl-xL, an inhibitor of programmed cell death. Nature 1996; 381 335-341.

11. Aritomi M, Kunishima N, Inohara N, Ishibashi Y, Ohta S, Morikawa K. Crystal structure of rat Bcl-xL. Implications for the function of the Bcl-2 protein family. J Biol Chem 1997; 272 27886-27892.

12. Dutta S, Gulla S, Chen TS, Fire E, Grant RA, Keating AE. Determinants of $B H 3$ binding specificity for Mcl-1 versus Bcl-xL. J Mol Biol 2010; 398: 747-762.

13. Fire $\mathrm{E}$, Gulla SV, Grant RA, Keating AE. Mcl-1-Bim complexes accommodate surprising point mutations via minor structural changes. Protein Sci 2010; 19: 507-519.

14. Liu X, Dai S, Zhu Y, Marrack P, Kappler JW. The structure of a Bcl-xL/Bim fragment complex: implications for Bim function. Immunity 2003; 19: 341-352.

15. Ku B, Liang $C$, Jung JU, Oh BH. Evidence that inhibition of BAX activation by BCL-2 involves its tight and preferential interaction with the $\mathrm{BH} 3$ domain of BAX. Cell Res 2011; 21: 627-641.

16. Letai A. Puma strikes Bax. J Cell Biol 2009; 185: 189-191.

17. Kim H, Tu HC, Ren D, Takeuchi O, Jeffers JR, Zambetti GP et al. Stepwise activation of BAX and BAK by tBID, BIM, and PUMA initiates mitochondrial apoptosis. Mol Cell 2009; 36 : 487-499.

18. Czabotar PE, Westphal D, Dewson G, Ma S, Hockings C, Fairlie WD et al. Bax crystal structures reveal how $\mathrm{BH} 3$ domains activate $\mathrm{Bax}$ and nucleate its oligomerization to induce apoptosis. Cell 2013; 152: 519-531.

19. Chen L, Willis SN, Wei A, Smith BJ, Fletcher Jl, Hinds MG et al. Differential targeting of prosurvival $\mathrm{Bcl}-2$ proteins by their $\mathrm{BH}$-only ligands allows complementary apoptotic function. Mol Cell 2005; 17: 393-403.

20. Walensky LD, Kung AL, Escher I, Malia TJ, Barbuto S, Wright RD et al. Activation of apoptosis in vivo by a hydrocarbon-stapled BH3 helix. Science 2004; 305: 1466-1470.

21. Walensky LD, Pitter K, Morash J, Oh KJ, Barbuto S, Fisher J et al. A stapled BID BH3 helix directly binds and activates BAX. Mol Cell 2006; 24: 199-210.

22. Labelle JL, Katz SG, Bird GH, Gavathiotis E, Stewart ML, Lawrence C et al. A stapled BIM peptide overcomes apoptotic resistance in hematologic cancers. J Clin Invest 2012; 122 2018-2031.

23. Lessene G, Czabotar PE, Colman PM. BCL-2 family antagonists for cancer therapy. Nat Rev Drug Discov 2008; 7: 989-1000.

24. Oltersdorf T, Elmore SW, Shoemaker AR, Armstrong RC, Augeri DJ, Belli BA et al. An inhibitor of Bcl-2 family proteins induces regression of solid tumours. Nature 2005; 435 : $677-681$.

25. Tse C, Shoemaker AR, Adickes J, Anderson MG, Chen J, Jin S et al. ABT-263: a potent and orally bioavailable Bcl-2 family inhibitor. Cancer Res 2008; 68: 3421-3428.

26. Hsieh AC, Truitt ML, Ruggero D. Oncogenic AKTivation of translation as a therapeutic target. Br J Cancer 2011; 105: 329-336.

27. Kwiatkowska A, Symons M. Signaling determinants of glioma cell invasion. Adv Exp Med Biol 2013; 986: 121-141.
28. Bellacosa A, Kumar CC, Di Cristofano A, Testa JR. Activation of AKT kinases in cancer: implications for therapeutic targeting. Adv Cancer Res 2005; 94: 29-86.

29. Ubersax JA, Ferrell JE Jr. Mechanisms of specificity in protein phosphorylation. Nat Rev Mol Cell Biol 2007; 8: 530-541.

30. Sattler M, Liang H, Nettesheim D, Meadows RP, Harlan JE, Eberstadt M et al. Structure of Bcl-xL-Bak peptide complex: recognition between regulators of apoptosis. Science 1997; 275: 983-986.

31. Oberstein A, Jeffrey PD, Shi Y. Crystal structure of the Bcl-XL-Beclin 1 peptide complex: Beclin 1 is a novel BH3-only protein. J Biol Chem 2007; 282: 13123-13132.

32. Maehama T, Dixon JE. The tumor suppressor, PTEN/MMAC1, dephosphorylates the lipid second messenger, phosphatidylinositol 3,4,5-trisphosphate. J Biol Chem 1998; 273 : 13375-13378.

33. McCall P, Witton CJ, Grimsley S, Nielsen KV, Edwards J. Is PTEN loss associated with clinical outcome measures in human prostate cancer? Br J Cancer 2008; 99: 1296-1301.

34. Nur EKA, Gross SR, Pan Z, Balklava Z, Ma J, Liu LF. Nuclear translocation of cytochrome c during apoptosis. J Biol Chem 2004; 279: 24911-24914.

35. Gelinas C, White E. BH3-only proteins in control: specificity regulates MCL-1 and BAKmediated apoptosis. Genes Dev 2005; 19: 1263-1268.

36. Wang C, Youle RJ. Predominant requirement of Bax for apoptosis in HCT116 cells is determined by Mcl-1's inhibitory effect on Bak. Oncogene 2012; 31: 3177-3189.

37. Ryou S, Yeom J, Kang H, Won M, Kim J, Lee B et al. Gold nanoparticle-DNA aptamer composites as a universal carrier for in vivo delivery of biologically functional proteins. J Cont Rel 2014; 196: 287-294.

38. Cheng JQ, Godwin AK, Bellacosa A, Taguchi T, Franke TF, Hamilton TC et al. AKT2, a putative oncogene encoding a member of a subfamily of protein-serine/threonine kinases, is amplified in human ovarian carcinomas. Proc Natl Acad Sci USA 1992; 89: 9267-9271.

39. Pal SK, Childs BH, Pegram M. Triple negative breast cancer: unmet medical needs. Breast Cancer Res Treat 2011; 125: 627-636.

40. Al-Saad S, Donnem T, Al-Shibli K, Persson M, Bremnes RM, Busund LT. Diverse prognostic roles of Akt isoforms, PTEN and PI3K in tumor epithelial cells and stromal compartment in non-small cell lung cancer. Anticancer Res 2009; 29: 4175-4183.

41. Abida WM, Gu W. p53-Dependent and p53-independent activation of autophagy by ARF. Cancer Res 2008; 68: 352-357.

42. Sherr CJ. The INK4a/ARF network in tumour suppression. Nat Rev Mol Cell Biol 2001; 2 : 731-737.

43. Moritz A, Li Y, Guo A, Villen J, Wang Y, MacNeill J et al. Akt-RSK-S6 kinase signaling networks activated by oncogenic receptor tyrosine kinases. Sci Signal 2010; 3: ra64.

44. Otwinosky Z, Minor W. Processing of X-ray diffraction data collected in oscillation mode. Methods Enzymol 1997; 276: 307-326.

45. Vagin A, Teplyakov A. Molecular replacement with MOLREP. Acta Crystallogr D Bio Crystallogr 2010; 66: 22-25.

46. Ku B, Woo JS, Liang C, Lee KH, Hong HSE X et al. Structural and biochemical bases for the inhibition of autophagy and apoptosis by viral $\mathrm{BCL}-2$ of murine gamma-herpesvirus 68 . PLoS Pathog 2008; 4: e25.

47. Emsley P, Cowtan K. Coot: model-building tools for molecular graphics. Acta Crystallogr $D$ Biol Crystallogr 2004; 60: 2126-2132

48. Brunger AT, Adams PD, Clore GM, DeLano WL, Gros P, Grosse-Kunstleve RW et al. Crystallography \& NMR system: A new software suite for macromolecular structure determination. Acta Crystallogr D Biol Crystallogr 1998; 54: 905-921

49. Adams PD, Afonine PV, Bunkoczi G, Chen VB, Davis IW, Echols N et al. PHENIX: a comprehensive Python-based system for macromolecular structure solution. Acta Crystallogr D Biol Crystallogr 2010; 66: 213-221.

50. Schrodinger L. The PyMOL Molecular Graphics System, Version 1.3r1 2010.

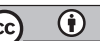

Cell Death and Disease is an open-access journal published by Nature Publishing Group. This work is licensed under a Creative Commons Attribution 4.0 International License. The images or other third party material in this article are included in the article's Creative Commons license, unless indicated otherwise in the credit line; if the material is not included under the Creative Commons license, users will need to obtain permission from the license holder to reproduce the material. To view a copy of this license, visit http://creativecommons.org/licenses/by/4.0/ 